\title{
Total Assets Turnover Against Dividend Payout Ratio: The Role of Return On Assets Mediation
}

\author{
Ira Puspita Setyaningsih ${ }^{1}$ and Indah Yuliana ${ }^{2}$ \\ ${ }^{1,2}$ Maulana Malik Ibrahim State Islamic University of Malang: Management, Malang, East Java, Indonesia
}

\begin{abstract}
The research objective is to examine the direct effect of TATO and ROA on the DPR, TATO on ROA, and the indirect effect of TATO on the DPR through ROA in the consumer goods industry sector in 2016-2018. The study population was all companies in the consumer goods industry sector with a total of 38 companies, while the samples taken were 21 companies. This type of research is quantitative research using Warp Partial Least Square (Warp-PLS) for data analysis. The direct effect test results show that TATO has no significant effect on the DPR, TATO significantly influences ROA and ROA significantly influences DPR. While the results of indirect influence testing prove that TATO significantly influences DPR through ROA, so the higher ROA is closer to the relationship between TATO and DPR.
\end{abstract}

Keywords - Total Assets Turnover (TATO); Return on Assets (ROA); Dividend Pay-out Ratio (DPR)

\begin{abstract}
Abstrak
Tujuan penelitian adalah menguji pengaruh langsung TATO dan ROA pada DPR, TATO pada ROA, serta pengaruh tidak langsung TATO pada DPR melalui ROA di sektor industri barang konsumsi tahun 2016-2018. Populasi penelitian adalah semua perusahaan sektor industri barang konsumsi dengan total 38 perusahaan, sedangkan sampel yang diambil sebanyak 21 perusahaan. Jenis penelitian adalah penelitian kuantitatif dengan menggunakan Warp Partial Least Square (Warp-PLS) untuk alisis data. Hasil pengujian pengaruh langsung menunjukan bahwa TATO secara signifikan tidak berpengaruh terhadap DPR, TATO secara signifikan berpengaruh terhadap $R O A$ dan $R O A$ secara signifikan berpengaruh terhadap $D P R$. Sedangkan hasil pengujian pengaruh tidak langsung membuktikan bahwa TATO secara signifikan berpengaruh terhadap DPR melalui $R O A$, sehingga semakin tinggi $R O A$ semakin erat hubungan antara TATO dan DPR.
\end{abstract}

Kata Kunci-Total Assets Turnover (TATO); Return On Assets (ROA); Dividend Payout Ratio (DPR)

\section{INTRODUCTION}

One of the sectors in manufacturing companies in Indonesia is the consumer goods industry sector. This sector consists of 6 subsectors with a total of 53 companies, namely the food and beverage sub-sector consisting of 26 companies, the household appliances subsector 4 companies, the cigarette subsector 4 companies, the cosmetics and household goods subsector of 6 companies, the pharmaceutical subsector 12 companies and the subsector others consist of 1 company (Kayo, 2012). Companies in this sector are enough to become potential investors for investing in funds because stocks in this sector are warning of an upside potential. In addition, this sector produces products that are needed by the community and is consumptive so that the possibility of developing is quite high considering the increasing population in Indonesia also causes an increase in the number of requests. Since the beginning of 2018 the consumer goods industry sector recorded an average correction in the stock price index of $13.77 \%$ and experienced a recovery of $3.69 \%$ (Pertiwi, 2018). The strengthening of the stock of the consumer goods industry sector occurred because of the tendency of American yields that began to be corrected after the momentum of Ramadan and Eid which made sales of 30\% $-40 \%$ 
before Eid Al-Fitr, the New Year and curriculum changes. Since the beginning of 2018 the consumer goods industry sector recorded an average correction in the stock price index of $13.77 \%$ and experienced a recovery of $3.69 \%$. The strengthening of the stock of the consumer goods industry sector occurred because of the tendency of American yields that began to be corrected after the momentum of Ramadan and Eid which made sales of $30 \%-40 \%$ before Eid Al-Fitr, the New Year and curriculum changes. Since the beginning of 2018 the consumer goods industry sector recorded an average correction in the stock price index of $13.77 \%$ and experienced a recovery of $3.69 \%$. The strengthening of the stock of the consumer goods industry sector occurred because of the tendency of American yields that began to be corrected after the momentum of Ramadan and Eid which made sales of 30\% -40\% before Eid Al-Fitr, the new year and curriculum changes (Pertiwi, 2018).

Seeing the considerable potential that exists in the consumer goods industry makes the content sector one of the goals for potential investors to invest their capital. Considering the main purpose of investors in investing, which is to get benefits or returns derived from payment of cash dividends and capital gains, the food and beverage industry sector is one of the objects of a pretty good investment. Distribution of a company's dividends depends on the company's agreement to pay all net income as dividends or hold it for reinvestment. In addition, dividend payment policy is considered as having good connotation for investors to see how the performance of a company. According to Megginson (1997: 362) dividend payments are very expensive, said to be very expensive because in dividend payments companies must use some of the funds used to make investments in addition to that investors who receive dividend payments must also pay taxes on the dividends it receives. This indicates that if a company is strong and has good performance that is able to pay dividends, while companies with limited ability will have difficulty making dividend payments. The amount of corporate profits paid into dividends by companies is shown by the dividend pay-out ratio (DPR). The following is the average dividend payment ratio in the consumer goods industry sector for three years.

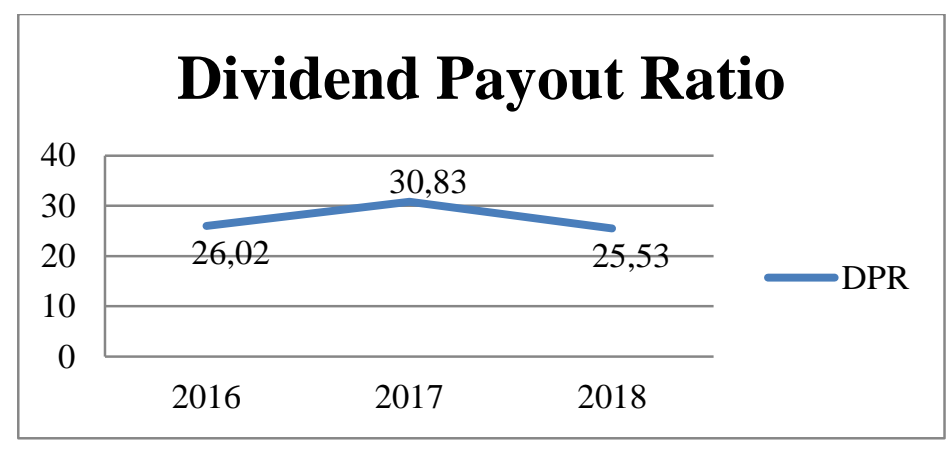

Graph 1. Average DPR for the consumer goods industry sector 2016-2018 (Source: processed data, 2019)

Based on the graph it can be seen that there was an increase from 2016 by $26.02 \%$ to $30.83 \%$ in 2017. However, in 2018 there was a decline to $25.53 \%$. It is known that in recent years there has been a slowdown in growth in the consumer goods industry due to several factors including the occurrence of increasingly fierce competition and heating up between companies of various local and foreign brands. In addition, the purchasing power of the people is experiencing a slowdown in purchasing power recovery and a shift in consumer choices from fast moving consumer good (FMCG) products to non-FMCG products that has slowed the growth of the consumer goods industry. Bank Indonesia survey results also state that the real sales index shows a decline in growth in recent years which is also in line with the slowdown in the consumer goods industry. Because of this phenomenon in recent years the profits of the company also experienced a decline so that the average dividend distributed by companies in this sector experienced a fluctuation. Seeing the fluctuation in the average DPR, of course there are many factors that influence it.

Total assets turnover is a factor that is considered to have an influence on the company's dividend pay-out ratio. Total assets turnover is used to explain the level of effectiveness of the use of assets (assets) obtained by a company. The amount of circulation of assets owned will show the company's financial performance. In other words, a company that has a large asset circulation can reflect the magnitude of the company's ability to pay dividends, and vice versa if the circulation of assets of a small companies then the ability of dividend payments will also be small. 
Research that proves that the dividend pay-out ratio is influenced by the total assets turnover significantly ('Analisis Faktor-Faktor Yang Mempengaruhi Kebijakan Dividen', n.d.; Firdaus \& Handayani, 2019; Fuadi \& Satini, 2015; Kuniawan et al., 2016; Purnami \& Artini, n.d.; Sabri et al., 2018; Wijaya, 2017). The results of the study contradict the findings (Choridah \& Diana, 2019; Mardiyati, 2014) which found no significant effect between the dividend pay-out ratio and total assets turnover.

Seeing the findings of previous studies which still show different results, therefore this study adds a variable return on assets as a mediator of the relationship between dividend pay-out ratio and total asset turnover. Return on assets describes the percentage of net profit obtained in managing company assets in order to obtain profits or profits during operational activities. The company's best profit will increase the total dividend that will be paid, because the dividend paid is part of the net profit of the company, so the size of the profits obtained will have an influence on the amount of dividend paid.

The results of previous studies found ROA significantly affect the DPR (Ahmad and Wardani, 2014; AlKayed, 2017; Baker, Dewasiri, Yatiwelle Koralalage, and Azeez, 2019; Basuki and Kuswanto, 2016; Gean Karlos Purba, 2019; Mardiyati, 2014; Mubarok, 2016; Pradana and Sanjaya, 2017 ). A different result was stated by (Lindi et al., 2019) namely that the DPR was not significantly affected by ROA but was marked negative. However, some researchers also found that DPR was not significantly affected by ROA('Analisis Faktor-Faktor Yang Mempengaruhi Kebijakan Dividen', n.d.; Kuniawan et al., 2016; Swastyastu et al., 2014) this is because company managers will calculate or consider an increase in the level of costs in the future when the company experiences growth.

The research objectives are (1) to determine the direct effect of TATO and ROA on the DPR; (2) know the direct effect of TATO on ROA, and; (3) knowing the indirect effect of TATO on the DPR is mediated by ROA on the consumer goods industry sector on the BEI 2016-2018.

\section{LITERATURE REVIEW}

\section{A. Total Assets Turnover Direct effect on Dividend Payout Ratio}

Dividend pay-out ratio (DPR) shows the tendency of companies to pay dividends by showing a comparison between the amount of dividend payments and the amount of net profit obtained by the company. This ratio refers to the percentage of the company's net profit income which will be paid as a dividend. This is aimed at increasing the value of the DPR, also increasing the net profit paid into dividends.

Total turnover assets (TATO) are one of the activity ratios showing the comparison of total assets or assets with the level of sales of a company. TATO illustrates the size of the circulation of assets or assets in a company, if the company's activity increases, the profit generated also increases (Simanjuntak, 2016). With the increase in the company's profits, dividend payments to investors will increase.

Research results found ('Analisis Faktor-Faktor Yang Mempengaruhi Kebijakan Dividen', n.d.; Fuadi \& Satini, 2015; Kuniawan et al., 2016; Purnami \& Artini, n.d.; Sabri et al., 2018; Wijaya, 2017) stated that the DPR was significantly influenced by TATO. This happens because the company's ability to distribute its assets is good, so that the company's sales level will increase and spur a large increase in profits and can sustain the company in carrying out its obligations to shareholders to carry out dividend payments(Fuadi \& Satini, 2015). A high activity ratio in a company can give a positive sign that the company's condition is good and can pay dividends to investors (Wijaya, 2017).

H1: TATO has a significant direct effect on the DPR

\section{B. Total Assets Turnover directly affect Retun on Assets}

Return on Assets (ROA) shows the ability of a company to manage the total assets / assets it owns to get maximum net profit. To evaluate the company's profitability this ratio is used by management by looking at managing total assets in the company. Increased ROA shows the best management of a company's total assets to obtain a higher profit.

TATO shows the total net sales of a company resulting from the management of its assets or assets. Increasing TATO shows that the management of assets of a company to obtain total net income is more effective. The high level of effectiveness reflects the achievement of good performance in a company. This 
reflects the greater level of sales achieved by the company can affect the amount of revenue generated by the company. Increasing the number of sales achieved by a company, the profits generated also increase. The good performance of a company is reflected in the value of good ROA as well (Utami \& Prasetiono, 2016).

The results of previous studies found by (Ambarwati and Sinarwati, 2015; Santi, 2019; Supardi, H. Suratno, and Suyanto, 2018; Susetyo, 2018; Utami and Prasetiono, 2016)states that ROA is significantly affected by TATO. The increasing sales activity in the company, the profitability reflected by ROA will also be even greater(Santi, 2019).

\section{H2: TATO has a significant direct effect on ROA}

\section{Retun on AssetsDirect effect on Dividend Payout Ratio}

Effective and efficient asset management in a company can make the company's profit or profit stable. The amount of the company's profit which is reflected by the value of ROA shows the ability of a company to pay dividends. Where the dividend payment of a company is taken from the acquisition of net profits, when the profits of the company the greater the dividend will also be high. This is because dividend payments will only be made when the company experiences profits or is in a state of making large profits, when the company earns low profits or suffers losses, dividend payments will be impossible for the company (Pradana and Sanjaya, 2017).

The results of previous studies found ROA directly affected the DPR significantly(Ahmad and Wardani, 2014; Al-Kayed, 2017; Baker et al., 2019; Basuki and Kuswanto, 2016; Gean Karlos Purba, 2019; Mardiyati, 2014; Mubarok, 2016; Pradana and Sanjaya, 2017). When the value of ROA is greater, it will show the better performance of the company and the impact on the level of return on investment of the company. The greater the value of ROA will increase the amount of dividends paid by the company.

H3: ROA has a significant direct effect on the DPR

\section{Total Assets Ratio indirectly affect the Dividend Payout Ratio through Retun on Assets}

TATO illustrate the amount of assets or assets turnover in a company, if the company's activities get bigger then the profit or profit will also increase. An increase in company profitability can increase the amount of dividend payments to investors as illustrated by the DPR's value.

Meanwhile, the high value of the company's ROA reflects the better performance and the assets owned are also sufficient to pay dividends. If the company's ROA continues to increase, the dividend payment will also increase. A company with a stable level of profit every year can be a reference for investors so they are sure to invest. Conversely, if a company always loses, investors will certainly be reluctant to invest because investors invest to get large profits, not vice versa.

ROA become an intervening variable to mediate the indirect effect between TATO and the DPR. Many previous studies have found that ROA directly affects the DPR significantly, so ROA is used as a mediator or intermediary between TATO and the DPR is expected to make an indirect relationship between the two becomes significant.

H4: TATO has a significant indirect effect on the DPR through ROA

\section{RESEARCH METHODS}

This type of quantitative research was chosen in this study with a total population of 38 companies in the consumer goods industry sector in the period 2016-2018. Samples were taken using positive sampling with the following conditions: (1) companies incorporated on the Stock Exchange in 2016-2018; (2) always get profit; (3) consistently distributing dividends. The following code is 21 companies that become the study sample, CEKA, CINT, DLTA, DVLA, GGRM, HMSP, ICBP, INDF, KAEF, KINO, KLBF, BRAND, MLBI, MYOR, BREAD, SIDO, SKLT, TCID, TSPC, ULTJ, and UNVR.

The dependent variable of the study is the Dividend Payout Ratio. According to Murhadi (2015: 65) Dividend Pay-out Ratio formula is:

$$
D P R=\frac{\text { Dividend }}{\text { EAT }}
$$


The independent variable of research is h Total Assets Turnover. According to Gitman and Zutter (2015) formula Total Assets Turnover is:

$$
\text { TATO }=\frac{\text { Penjualan Bersih }}{\text { Total Aktiva }}
$$

Intervening research variable is hReturn on Asstes. According to Hermanto and Agung (2015) formula Return on Assets is:

$$
R O A=\frac{\text { EAT }}{\text { Total aset }}
$$

Warp Partial Least Square (Warp-PLS) 6.0 is used to analyse data by testing measurement and structural models. Here is a conceptual framework of research.

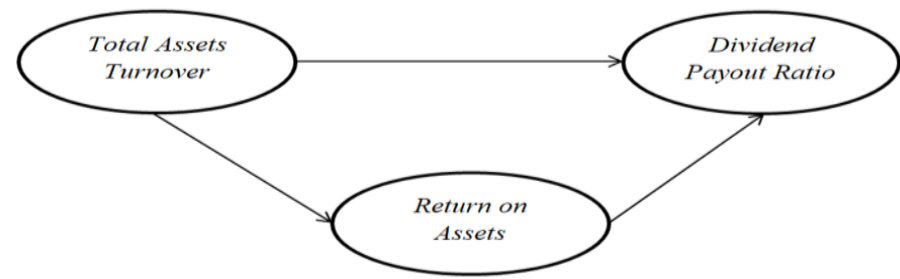

Figure 1. Conceptual Framework

\section{RESULTS AND DISCUSSION}

\section{A. Evaluation of Measurement Model}

\section{Convergent Validity}

Converging validity the measurement model is known from the size of the loading factor value of each indicator with the condition that the loading factor $>0.7$ can be declared valid and significant is when the value of $\mathrm{p}$-value $<0.05$. Here are the results of combined loadings and cross-loadings.

Table 1. Results of combined loadings and cross-loadings

\begin{tabular}{lccccc}
\hline Indicator & TATO & ROA & DPR & SE & P value \\
\hline TATO & $(1,000)$ & 0,000 & 0,000 & 0.089 & $<0.001$ \\
ROA & 0,000 & $(1,000)$ & 0,000 & 0.089 & $<0.001$ \\
DPR & 0,000 & 0,000 & $(1,000)$ & 0.089 & $<0.001$ \\
\hline
\end{tabular}

Source: data obtained (2019)

These results indicate that the loading value for TATO, ROA and DPR is 1,000 and the p-value shows a number $<0.001$ for all indicators. These results indicate that all indicators are valid as a measure of latent variables.

Besides looking at the loading factor value, the Average Variance Extracted (AVE) value is also used to see the measurement of convergent validity with the requirement of AVE>0.5. Here are the results of Average Variance Extracted.

Table 2. Average Variance Extracted Value (AVE)

\begin{tabular}{llcc}
\hline Variable & AVE & Provisions & Information \\
\hline TATO & 1,000 & $>0.5$ & Valid \\
ROA & 1,000 & $>0.5$ & Valid \\
DPR & 1,000 & $>0.5$ & Valid \\
\hline
\end{tabular}


These results indicate that the AVE value for TATO, ROA and DPR is 1,000 (AVE value> 0.50). These results state the AVE value of all variables has reached the criteria of convergent validity.

\section{$\underline{\text { Reliability Test }}$}

Reliability tests are known from the magnitude of the composite reliability and Cronbach's alpha values, each of which has a requirement of $>0.7$ and $>0.6$. The following are the composite reliability and cronbach's alpha values.

Table 3 Composite reliability and cronbach's alpha values

\begin{tabular}{lccccc}
\hline & TATO & ROA & DPR & Criteria & Information \\
\hline Composite Reliability & $(1,000)$ & $(1,000)$ & $(1,000)$ & $>0.70$ & Reliable \\
Conbach's Alpha & $(1,000)$ & $(1,000)$ & $(1,000)$ & $>0.60$ & Reliable \\
\hline
\end{tabular}

Source: processed data (2019)

The above results show if the Composite Reliability value of the TATO variable, ROA of DPR funds is as large as 1 which is $>0.70$ and the Cronbach's Alpha value also shows each variable of 1 which is>0.60. These results indicate if all the variables used have met the reliability criteria which mean the gauge of each variable is highly correlated.

\section{B. Evaluation of Structural Models}

In the structural model evaluation there are three indices used to test the average path coefficient (APC) and the average R-squared (ARS) with the condition that the p-value $<0.05$ and the average variance factor (AFIV) with the AVIF condition <5. Following are the results of APC, ARS and AVIF.

Table 4. Results APC, ARS and AVIF

\begin{tabular}{llcc}
\hline & Index & $P$-value & Criteria \\
\hline APC & .402 & $<0.001$ & $<0.05$ \\
ARS & .371 & $<0.001$ & $<0.05$ \\
AVIF & 1,393 acceptable if $<=5$, ideally $<=3,3$ & & $<5$ \\
\hline
\end{tabular}

Source: data obtained (2019

Based on these results, the APC and ARS p-values are <0.001 and the AVIF value is 1.393 so that the evaluation of the structural model of this study can be accepted.

\section{Hypothesis Testing Results}

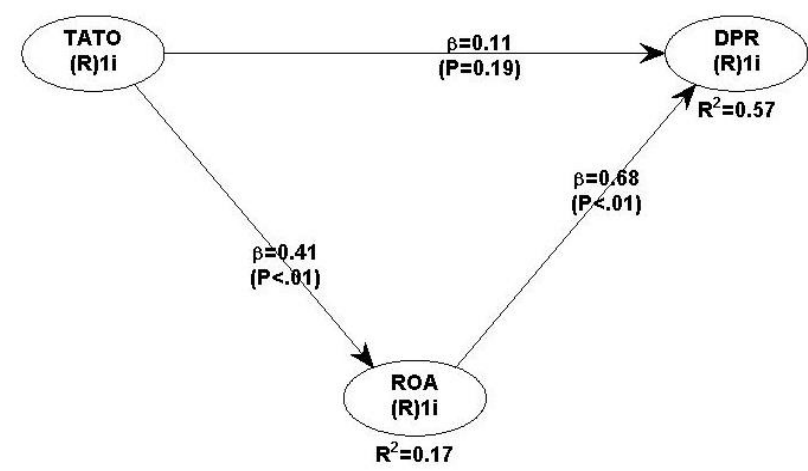

Figure 2. Results of structural equation models using Warp-PLS (Source: Warp-PLS data processing output, 2019)

Hypothesis testing is done by looking at the relationship between constructs based on the magnitude of the value of the path coefficients and the $p$-value in determining the significance of the relationship. According to Solimun, Fernandes, and Nurjanah (2017) if the p-value $\leq 0.10$ is significantly weak, p-value $\leq 0.05$ is significant and $\mathrm{p}$-value $\leq 0.01$ indicates a high level of significance. Here are the results of the hypothesis test: 
Table 5. Hypothesis Test Results

\begin{tabular}{llll}
\hline Relationship & Path Coefficients & P-value & Information \\
\hline TATO $(\mathrm{X}) \rightarrow$ DPR $(\mathrm{Y})$ & .109 & .185 & Not significant \\
TATO $(\mathrm{X}) \rightarrow$ ROA $(\mathrm{Z})$ & 0.413 & $<0.001$ & Significant \\
ROA $(\mathrm{Z}) \rightarrow$ DPR $(\mathrm{Y})$ & .685 & $<0.001$ & Significant \\
TATO $(\mathrm{X}) \rightarrow$ ROA $(\mathrm{Z})$ DPR $(\mathrm{Y}) \rightarrow$ & .283 & $<0.001$ & Significant \\
\hline
\end{tabular}

Source: processed data (2019)

The results above show that the value of the path coefficient (path coefficient) from TATO to the DPR is 0.109 with a p-value of 0.185 so that the DPR is not significantly affected by TATO. The results of this study reject $\mathrm{H} 1$, namely TATO has a significant direct effect on the DPR.

The value of the path coefficient (path coefficient) from TATO to ROA of 0.413 with $p$-value $<0.001$ so that ROA is significantly influenced by TATO. The results of this study accept H2 that TATO has a significant direct effect on ROA.

The value of the path coefficient from ROA to the DPR is 0.685 with a p-value $<0.001$ so that the DPR is significantly affected by ROA. The results of this study accept H3 namely ROA significantly direct effect on the DPR.

It is known that the path coefficient value between TATO and DPR through ROA is 0.283 with p-value $<0.001$ so that DPR is influenced by TATO indirectly and significantly through ROA. This result accepts H4, ie TATO has a significant indirect effect on the DPR through ROA.

\section{Discussion}

\section{Total Assets Turnover has a direct significant effect on Dividend Payout Ratio}

The results show that H1, TATO, which has a significant direct effect on the DPR is rejected. Based on these results it appears that the high or low TATO in business entities is not a reference for companies to take dividend payment policies. The company pays more attention to profits earned during the period rather than pay attention to the ratio of TATO it has.

This research supports (Choridah and Diana, 2019)which states that the size of the TATO of a company does not become a reference company in taking dividend payment policies because the company pays more attention to profits earned during the current period than pay attention to the ratio of the total asset turnover it has. The same result by Dewi (2013), Lindi et al. (2019), and Mardiyati (2014) which states TATO has no significant effect on the DPR. This finding is contrary to stated that the DPR was significantly influenced by TATO (Firdaus and Handayani, 2019; Fuadi and Satini, 2015; Kuniawan et al., 2016; Nugroho, 2019; Purnami and Artini, 2016; Sabri et al., 2018; Simaanjuntak, 2016; Wijaya, 2017).

\section{Total Assets Turnover significant direct effect on Return On Assets}

The results show that $\mathrm{H} 2$, TATO, which has a significant direct effect on ROA is proven. Based on these results it shows that the increase in TATO value will have an impact on increasing ROA. The high value of TATO of a company illustrates efficient asset management in supporting sales activities to generate profits. The more efficient the management of assets, the better the company's performance to get profits. The increase in profitability of the company can have an impact on the rising value of ROA.

These results support the findings states that ROA is significantly influenced by TATO(Ambarwati and Sinarwati, 2015; Santi, 2019; Supardi et al., 2018; Susetyo, 2018; Utami and Prasetiono, 2016). The increasing sales activity at the company, the profitability derived from the value of ROA will also increase(Santi, 2019).

\section{Return on Assets Significantly direct effect on Dividend pay-out Ratio}

The results show that H3, namely ROA, which has a significant direct effect on the DPR, is proven. These results indicate that if the company's profits continue to increase will increase the possibility of dividend payments made by the company. When a company experiences high profits or high operating profit, the company's ability to pay dividends will be large and vice versa when the company suffers losses, the smaller the ability to pay dividends. In other words, ROA is a factor that companies use as a reference in making policies to pay dividends. This result is in line with the findings that the DPR significantly influenced ROA (Ahmad and 
Wardani, 2014; Al-Kayed, 2017; Baker et al., 2019; Basuki and Kuswanto, 2016; Gean Karlos Purba, 2019; Mardiyati, 2014; Mubarok, 2016; Pradana and Sanjaya, 2017).

Total Assets Ratio significant indirect effect on Dividend Payout Ratio is influenced through Return on Assets

The results show that $\mathrm{H} 4$ namely TATO significantly indirect effect on the DPR through ROA is proven. These results show the significant and positive influence of ROA in mediating TATO and DPR. If the ROA value of the company increases, the magnitude of TATO's influence on the DPR will also increase. In this way ROA can strengthen the relationship between TATO and the DPR.

\section{CONCLUSIONS AND RECOMMENDATIONS}

This study found that the DPR was not significantly affected by TATO. High or low TATO in business entities does not become a reference in dividend payment policy. The company pays more attention to the profits earned during the current period than pay attention to the ratio of TATO it has. Besides ROA significantly affected TATO. The greater TATO value indicates that the use of all company assets to support sales activities is getting better and more efficient. The better and more efficient use of its assets, the management of a company is also better, which is shown by the high ROA value. Other results show that the DPR is significantly affected by ROA. The higher the profits, the company's ability to pay dividends is also greater. ROA is also able to mediate the influence of TATO on the DPR positively and significantly. The existence of ROA as mediation can strengthen the influence of TATO on the DPR. The limitation of this study is that the observation period is too short for only three years and it is feared that data will deviate. Researchers only used three variables namely TATO, ROA and DPR. Suggestions for further research is to increase the time period of the observation period to five years. Add more saving variables, for example using liquidity ratios, leverage or macroeconomic factors and expanding research objects to get more accurate results. The limitation of this study is that the observation period is too short for only three years and it is feared that data will deviate. Researchers only used three variables namely TATO, ROA and DPR. Suggestions for further research is to increase the time period of the observation period to five years. Add more saving variables, for example using liquidity ratios, leverage or macroeconomic factors and expanding research objects to get more accurate results. The limitation of this study is that the observation period is too short for only three years and it is feared that data will deviate. Researchers only used three variables namely TATO, ROA and DPR. Suggestions for further research is to increase the time period of the observation period to five years. Add more saving variables, for example using liquidity ratios, leverage or macroeconomic factors and expanding research objects to get more accurate results.

\section{REFERENCES}

Ahmad, G. N., \& Wardani, V. K. (2014). The effect of fundamental factor to dividend policy: Evidence in Indonesia Stock Exchange. International Journal of Business and Commerce, 4(2), 14-25.

Al-Kayed, L. T. (2017). Dividend payout policy of Islamic vs conventional banks: case of Saudi Arabia. International Journal of Islamic and Middle Eastern Finance and Management, 10(1), 117-128.

Ambarwati, N. S., Yuniarta, G. A., AK, S., \& SINARWATI, N. K. (2015). Pengaruh modal kerja, likuiditas, aktivitas dan ukuran perusahaan terhadap profitabilitas pada perusahaan manufaktur yang terdaftar di bursa efek Indonesia. JIMAT (Jurnal Ilmiah Mahasiswa Akuntansi) Undiksha, 3(1).

Baker, H. K., Dewasiri, N. J., Koralalage, W. B. Y., \& Azeez, A. A. (2019). Dividend policy determinants of Sri Lankan firms: a triangulation approach. Managerial Finance, 45(1), 2-20.

Basuki, B., \& Kuswanto, S. (2016). Pengaruh Profitabilitas, Leverage Dan Kepemilikan Institusional Terhadap Kebijakan Dividen. Jurnal Dinamika Umt, 1(2), 46-55.

Brigham, E. F., \& Houston, J. F. (2010). Dasar-Dasar Manajemen Keuangan, Edisi 11 Buku 1. Translated by Ali Akbar Yulianto. Jakarta: Salemba Empat.

Choridah, L., \& Diana, N. (2019). Analisis Fundamental Saham Terhadap Kebijakan Pembayaran Dividen (Studi Empiris Pada Perusahaan Manufaktur Yang Terdaftar Di Bursa Efek Indonesia. 08(09), 166-177.

Dewi, P. (2013). Pengaruh Cash Ratio, Return On Asset, Debt To Equity Ratio, Dan Total Asset Turnover Terhadap Kebijakan Dividen. Jurnal Universitas Bakrie, 1(3).

Fahmi, I. (2014). Analisis Laporan Keuangan. Cetakan Ke-4. Bandung: Alfabeta. 
Firdaus, I., \& Handayani, P. (2019). Pengaruh Der, Tato Dan Npm Terhadap Kebijakan Dividen (Studi Kasus Pada Industri Dasar Dan Kimia Yang Terdaftar Di Bursa Efek Indonesia (Bei) Tahun 2012-2016). Journal Of Applied Accounting And Finance, 3(1), 71-84.

Fuadi, R., \& Satini, A. J. (2015). Pengaruh Investment Opportunity Set, Total Asset Turn Over, Dan Earning Per Share Dengan Dividen Tunai (Studi Pada Perusahaan Manufaktur Yang Terdaftar Di Bei Periode 2009-2013). Jurnal Dinamika Akuntansi Dan Bisnis, 2(1), 70-81.

Gean Karlos Purba, I. F. 2019. Pengaruh Kinerja Keuangan Perusahaan Terhadap Devidend Payout Ratio. Jurnal Ekonomi, 24(1), 31-45.

Gitman, L. J., \& Zutter C. J. (2015). Principles Of Managerial Finance. Pearson Education

Hanafi, M. M. (2013). Manajemen Keuangan. Yogyakarta: Bpfe.

Hermanto, B., \& Agung, M. (2015). Analisa Laporan Keuangan. Lentera Ilmu Cendekia Jakarta

Kasmir. (2015). Analisis Laporan Keuangan. Jakarta : Rajawali Pers.

Kurniawan, E. R., Arifati, R., \& Andini, R. (2016). Pengaruh Cash Position, Debt Equity Ratio, Return On Asset, Current Ratio, Firm Size, Price Earning Ratio, Dan Total Assets Turn Over Terhadap Deviden Payout Ratio Pada Perusahaan Manufaktur Periode 2007-2014. 2(2), 339-351.

Kayo, E. S. (2012). Sektor Industri Barang Konsumsi. Sahamok.Net. https://www.sahamok.net/emiten/sektorindustri-barang-konsumsi/ (diakses 20 November 2019)

Lindi, P. Y., Sitepu, H. E. B., Tampubolon, S. D. E., Ginting, W. A., \& Purba, M. N. (2019). The Effects Of Cash Ratio (Cr), Total Asset Turnover (Tato), Return On Assets (Roa) On Dividend Payout Ratio (Dpr) In Various Goods Industri And Consumption Goods Industri Sektors Found In The Indonesia Stock Exchange In 2013-2017. Jurnal Ilmiah Esai , 13(2), 107-123.

Mardiyati, U. (2014). Pengaruh Free Cash Flow, Return On Assets, Total Assets Turnover Dan Sales Growth Terhadap Dividend Payout Ratio (Studi Pada Perusahaan Manufaktur Yang Terdaftar Di Bursa Efek Indonesia Periode 2008-2012). 5(2), 204-221.

Megginson, W. L. (1997). Corporate Finance Theory. Addison Wesley.

Mubarok, N. (2016). Pengaruh Current Ratio, Debt To Equity Ratio, Total Asset Turnover Dan Return On Asset Terhadap Dividend Payout Ratio Pada Perusahaan Sektor Industri Barang Konsumsi Yang Terdaftar Di Bursa Efek Indonesia. I-Finance, 2(2), 107-124.

Murhadi, W. R. (2015). Analisis Laporan Kuangan, Proyeksi Dan Valuasi Saham. Jakarta: Salemba Empat.

Nugroho, S. Y. (2019). Analisis Faktor-Faktor Yang Mempengaruhi Kebijakan Dividen. Jurnal Riset Akuntansi Dan Keuangan, 1(1), 43-54.

Pertiwi, D. S. (2018). Ini prospek cerah saham emiten barang konsumsi. https://investasi.kontan.co.id/news/iniprospek-cerah-saham-emiten-barang-konsumsi (diakses 20 November 2019)

Pradana, S. W. L., \& Sanjaya, I. P. S. (2017). Dampak Profitabilitas, Aliran Kas Bebas, Dan Kesempatan Investasi Terhadap Pembayaran Dividen Perusahaan Perbankan. Jurnal Keuangan Dan Perbankan, 21(1), 113-124.

Purnami, K. D. A., \& Artini, L. G. S. 2016. Pengaruh Investment Opportunity Set, Total Asset Turn Over Dan Sales Growth Terhadap Kebijakan Dividen. E-Jurnal Manajemen Unud, 5(2), 1309-1337.

Sabri, F. H., Deviyanti, D. R., \& Kurniawan, I. S. (2018). Pengaruh Kinerja Keuangan Terhadap Dividend Payout Ratio Studi Empiris Pada Perusahaan Bumn. Kinerja, 14(1), 24-30.

Santi, C. (2019). Pengaruh Tato Terhadap Return Saham Dengan Profitabilitas Sebagai Variabel Intervening Pada Perusahaan Otomotif Dan Komponen. Jurnal Analisa Akuntansi dan Perpajakan, 2(2), 30-41.

Simanjuntak, S. M. (2016). Pengaruh Return On Asset, Growth, Total Asset Turnover, Ownership, Firm Size Dan Debt To Total Asset Terhadap Dividend Payout Ratio Pada Perusahaan Yang Terdaftar Di Bursa Efek Indonesia Periode 2010-2012. Jurnal Lentera Akuntansi, 2(2), 101-116.

Supardi, H., H. Suratno, H. S., \& Suyanto, S. (2018). Pengaruh Current Ratio, Debt To Asset Ratio, Total Asset Turnover Dan Inflasi Terhadap Return On Asset. Jiafe (Jurnal Ilmiah Akuntansi Fakultas Ekonomi), 2(2), 16-27.

Susetyo, A. (2018). Analisis Pengaruh Current Ratio, Debt To Equity Ratio Dan Total Asset Turnover Terhadap Return On Asset Pada Perusahaan Yang Tercatat Di Jakarta Islamic Index. Jurnal Ilmiah Akuntansi Dan Keuangan, 6(1), 130-142.

Utami, R. B., \& Prasetiono, P. (2016). Analisis Pengaruh Tato, Wcto, Dan Der Terhadap Nilai Perusahaan Dengan Roa Sebagai Variabel Intervening (Studi Pada Perusahaan Manufaktur Yang Terdaftar Di Bursa Efek Indonesia Periode Tahun 2009-2013). Jurnal Studi Manajemen Organisasi, 13(1), 28-43.

Wijaya, R. (2017). Kinerja Keuangan Dan Ukuran Perusahaan Terhadap Harga Saham Dengan Kebijakan Dividen Sebagai Variabel Intervening. Jurnal Keuangan Dan Perbankan, 21(3), 459-472. 